\title{
Anatomical characteristics of macroalgal species from Bombuyanoi Island, East Bolaang Mongondow Regency, North Sulawesi
}

\author{
Indonesian title: \\ Karakteristik anatomi jenis makroalga dari Pulau Bombuyanoi, Kabupaten Bolaang \\ Mongondow Timur, Sulawesi Utara
}

\author{
Frian Patra ${ }^{1 *}$, Rene Ch. Kepel ${ }^{2}$, Lawrence J.L. Lumingas ${ }^{1}$, Grevo S. Gerung ${ }^{1}$, Khristin F. Kondoy ${ }^{2}$, \\ Deiske A. Sumilat ${ }^{1}$, Suzanne L. Undap ${ }^{2}$ \\ ${ }^{I}$ Program Studi Magister Ilmu Perairan, Fakultas Perikanan dan Ilmu Kelautan, Universitas Sam Ratulangi \\ Jl. Kampus Unsrat Bahu, Manado 95115 Sulawesi Utara, Indonesia \\ ${ }^{2}$ Fakultas Perikanan dan Ilmu Kelautan, Universitas Sam Ratulangi, Jl. Kampus Unsrat Bahu, \\ Manado 95115, Sulawesi Utara, Indonesia \\ *Corresponding author: frianpatra12@gmail.com
}

Received: 21 July 2021 - Revised: 12 September 2021 - Accepted: 13 September 2021

\begin{abstract}
This research aims to study the anatomical structure of macroalgae. Sample of macroalga was collected by using Line Intercept Transect (LIT) method with sampling quadrat. Macroalgae samples were dried and separated from the roots, stems, leaves and receptacles (if present). Samples were cut transversely and longitudinally at each section and observed under binoculared microscope of Olympus CX with monitor. Based on the histology, anatomical structure of macroalgae species can be divided into two tissues from outside to inside, namely cortex and medullary cells. The cortex is composed of one layer or more. The cortex is the area between the epidermis and the central column. The medulla cells only have one layer which is the largest layer. Based on the observation result of cells type from observed spesies Eucheuma denticilatum, Gracilaria arcuata, Hydropuntia edulis, G. salicornia, Hypnea valentiae, Turbinaria deccurens, and T. ornata, it shows that cells of medulla become small toward cortex.
\end{abstract}

Keywords: macroalgae; cell anatomy; cortex; medula; Bolaang Mongondow

\section{PENDAHULUAN}

Penelitian tentang jumlah jenis makroalga telah banyak dilakukan di Sulawesi Utara, di antaranya, penelitian tentang aspek biodiversitas di mana ditemukan 7 jenis di Mokupa, Kabupaten Minahasa (Wowor et al., 2015), 44 jenis di Pulau Mantehage (Watung et al., 2016), 15 jenis di Tongkaina, Kota Manado (Kepel et al., 2018a), 14 jenis di Blongko, Kabupaten Minahasa Selatan (Kepel et al., 2018b), 8 jenis di Bahoi, Kabupaten Minahasa Utara (Baino et al., 2019), 45 jenis di Pulau Mantehage, Kabupaten Minahasa Utara (Kepel et al., 2019a), 10 jenis di Kora-Kora, Kabupaten Minahasa (Kepel and Mantiri, 2019), dan di Semenanjung Minahasa di mana ditemukan 35 jenis pada musim hujan (Kepel et al., 2019b) dan 19 jenis pada musim kemarau (Kepel et al., 2020).

Pulau Bombuyanoi, yang masuk dalam administrasi pemerintahan Kabupaten Bolaang Mongondow Timur, merupakan salah satu pulau yang memiliki keindahan alam di wilayah tersebut. Hal ini menjadikannya sebagai destinasi wisata yang dapat menguntungkan perekonomian daerah dan masyarakat di daerah tersebut. Selain pantainya yang indah, pulau ini juga memiliki sumber daya pesisir yang besar berupa ekosistem terumbu karang, padang lamun, mangrove, dan makroalga. Tingginya tingkat pertumbuhan kunjungan masyarakat untuk berpariwisata, dikhawatirkan akan mengganggu keberadaan sumber daya di pulau tersebut. Sampai saat ini informasi tentang sumber daya laut, khususnya makroalga di Pulau Bombuyanoi, belum 
tersedia. Oleh karena itu, penelitian ini bertujuan untuk mendeskripsikan jenis makroalga dan menganalisis karakteristik anatomi jenis tersebut.

\section{MATERIAL DAN METODE}

\section{Waktu dan Tempat Penelitian}

Penelitian ini dilaksanakan pada bulan Agustus sampai dengan September 2020. Lokasi penelitian bertempat di perairan pesisir Pulau Bombuyanoi, Kecamatan Tutuyan, Kabupaten Bolaang Mongondow Timur. Pengambilan sampel dilakukan pada 3 lokasi.

\section{Pengambilan Sampel}

Penetapan lokasi pengambilan sampel ditentukan berdasarkan hasil survei lokasi yang dilakukan terlebih dahulu dengan melihat kondisi perairan yang ditumbuhi makroalga, di antaranya kondisi substrat dan bisa mewakili lokasi tersebut. Pengambilan sampel makroalga dilakukan dengan menggunakan metode line transect dengan teknik sampling kuadrat (Krebs, 1999).

Peletakan transek di masing-masing lokasi untuk pengambilan sampel dilakukan pada 3 garis sepanjang $50 \mathrm{~m}$, yang ditarik tegak lurus dengan garis pantai ke arah laut dengan asumsi penyebaran komunitas makroalga merata. Kuadrat yang digunakan berukuran $1 \times 1 \mathrm{~m}^{2}$. Setelah diambil, sampel dibersihkan terlebih dahulu dengan cara dicuci untuk mengeluarkan kotoran yang menempel, kemudian disimpan di lemari pendingin. Selanjutnya, di laboratorium, sampel diidentifikasi hingga pada tingkat jenis dengan menggunakan petunjuk identifikasi dari Calumpong and Meñez (1997), Trono (1997), dan WoRMS (2021).

\section{Anatomi Jenis}

Untuk anatomi jenis, sampel makroalga dikeringkan terlebih dahulu dan dipisahkan setiap bagiannya yaitu bagian akar, batang, daun, dan reseptakel (jika ada). Setelah dipisahkan, sampel dipotong secara melintang dan memanjang terhadap masing-masing bagian menggunakan pisau. Pemotongan dilakukan setipis mungkin agar struktur sel dapat terlihat jelas.

Hasil pemotongan bagian sampel, diletakkan pada kaca preparat dan diberikan cairan metylene blue yang sudah dicampur dengan air dengan perbandingaan 2:1. Kemudian sampel diamati menggunakan mikroskop binokuler merek Olympus CX 41 yang tersambung pada monitor. Pengamatan dilakukan pada titik fokus 100x. Hasil pengamatan disimpan secara digital dalam bentuk gambar.

\section{HASIL DAN PEMBAHASAN}

Tujuh jenis makroalga telah diamati dari lokasi penelitian di Pulau Bombuyanoi. Berikut ini adalah deskripsi anatomi dari tiap jenis dan habitatnya:

Eucheuma denticilatum (N.L. Burman) Collins \& Hervey 1917

Deskripsi: Thallus kecil, memanjang, dan berbentuk silindris, tidak berlendir, tinggi $10 \mathrm{~cm}$ dengan diameter $0,3 \mathrm{~cm}$. Terdapat cabang sekunder dengan ujung yang tajam. Cabang utama berbentuk rata, berwarna hijau muda saat masih segar dan hijau kecokelatan setelah kering. Bentuk tidak beraturan, melekat dengan alat pelekat (holdfast) (Gambar 1A-C).

Habitat: Tumbuh pada substrat berpasir dan pasir berbatu.

Gracilaria arcuata Zanardini, 1858

Deskripsi: Thallus lurus, alat pelekat berbentuk cakram. Percabangan tidak beraturan, sangat rimbun. Thallus padat dan tebal tingginya mencapai $10 \mathrm{~cm}$, berwarna merah kecokelatan (Gambar 2A-C).

Habitat: Substrat berpasir pada daerah intertidal.

Hydropuntia edulis (S.G. Gmelin) Gurgel \& Fredericq, 2004

Deskripsi: Thallus berbentuk silindris, tinggi 7,5-10 $\mathrm{cm}$, panjang $17 \mathrm{~cm}$. Bagian alat pelekat berbentuk cakram. Bercabang dikotom, kadang dijumpai tidak beraturan, pada bagian apeks biasanya mengecil dan melengkung waktu kering. Thallus berwarna cokelat kehijauan di alam dan cokelat tua saat kering (Gambar 3A-C).

Habitat: Substrat karang di rataan intertidal.

Gracilaria salicornia (C. Agradh) E.Y. Dawson, 1954

Deskripsi: Thallus berbentuk silindris, licin, bersegmen membentuk rumpun yang lebat, tinggi mencapai $7 \mathrm{~cm}$, bagian alat pelekat berbentuk cakram. Percabangan thallus berbentuk polystichous atau banyak cabang pada thallus utama. Berwarna hijau kekuningan 
Patra et al.: Anatomical characteristics of macroalgal species from Bombuyanoi Island, ...
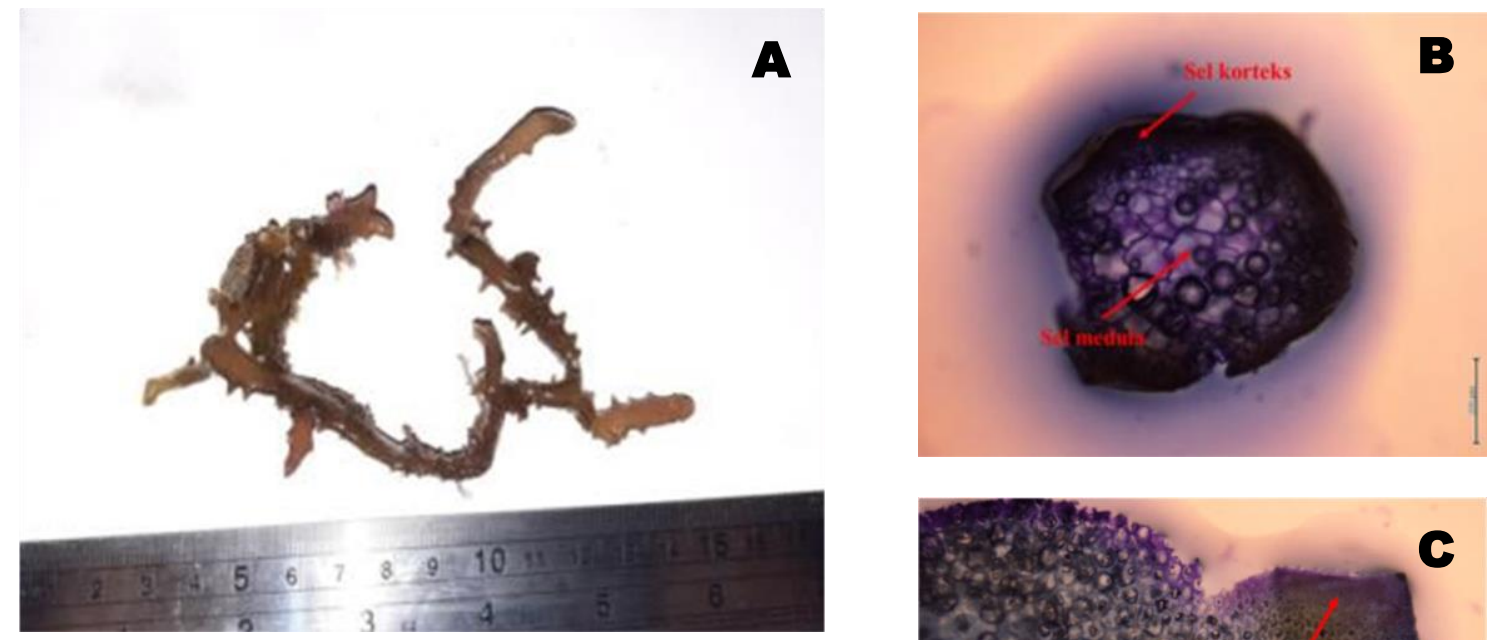

Gambar 1. Eucheuma denticilatum

A: Herbarium

B: Potongan melintang

C: Potongan memanjang
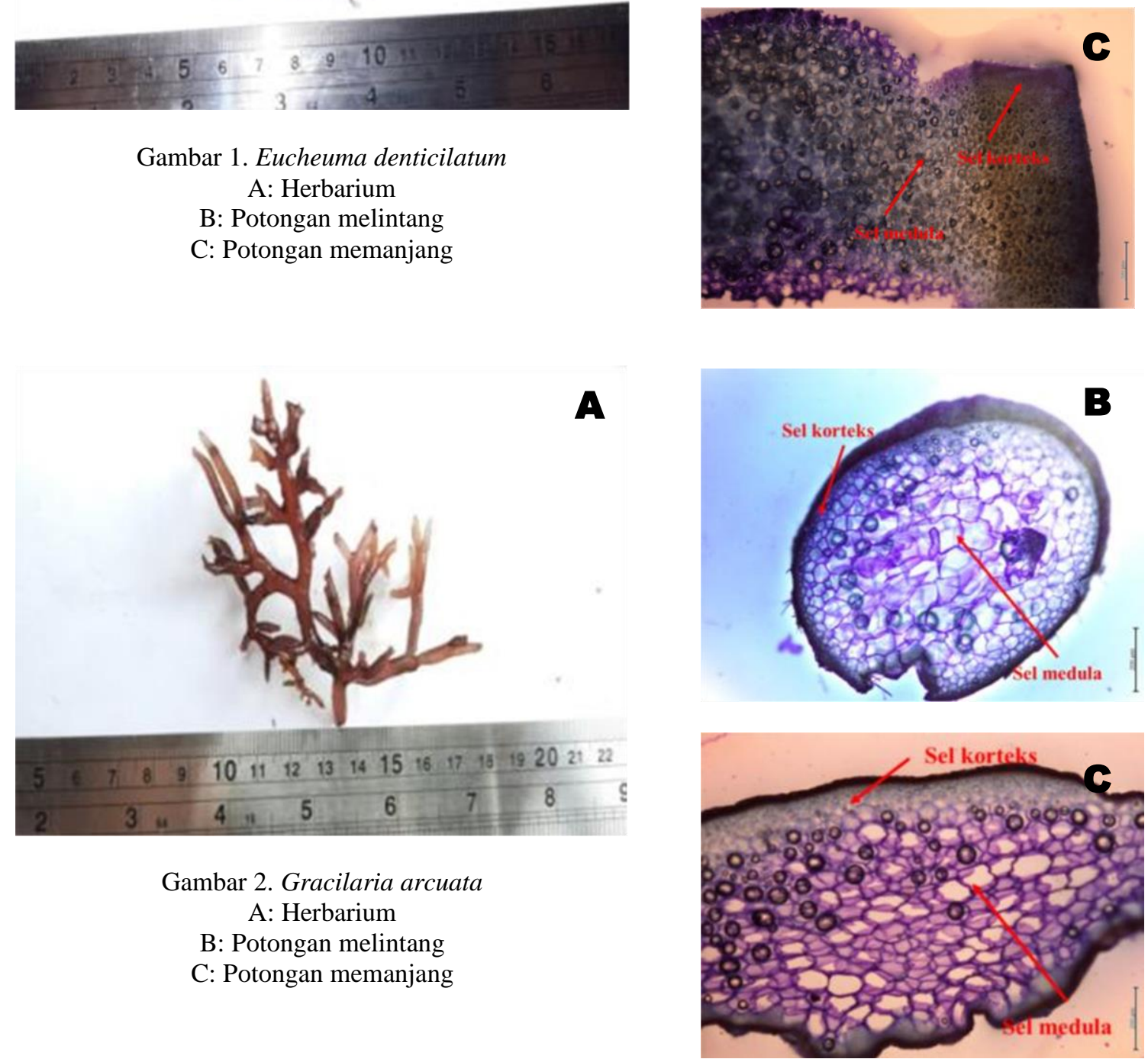

sampai orange di perairan jernih, pada perairan keruh berwarna cokelat tua (Gambar 4A-C).

Habitat: Substrat karang, batu, berpasir di rataan.

Hypnea valentiae (Turner) Montagne, 1841

Deskripsi: Thallus rimbun, bentuk percabangan tidak teratur dan memiliki percabangan berupa cabang-cabang kecil yang pendek. Thallus berwarna cokelat kehijauan (Gambar 5A-C).

Habitat: Substrat karang, batu, berpasir di rataan.
Turbinaria deccurens Bory de Saint Vincent, 1828

Deskripsi: Thallus tegak, tinggi total thallus 4,5-11 $\mathrm{cm}$, tinggi dari alat pelekat ke percabangan pertama $0,2-1 \mathrm{~cm}$, panjang $1-1,3 \mathrm{~cm}$ dan berwarna cokelat gelap. Memiliki reseptakel di antara daun. Alat pelekat tumbuh menjalar pada bagian bawah thallus menyerupai akar serabut (Gambar 6A-I).

Habitat: Substrat karang dan menyebar di rataan intertidal. 

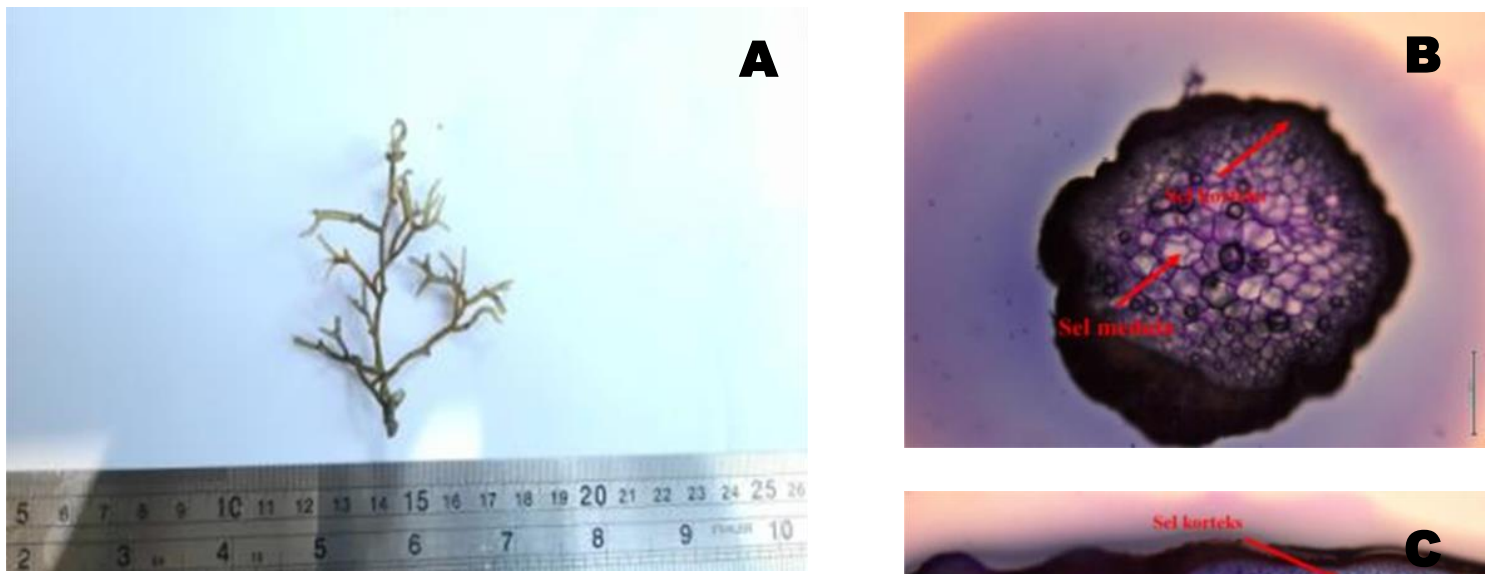

Gambar 3. Hydropuntia edulis A: Herbarium

B: Potongan melintang

C: Potongan memanjang
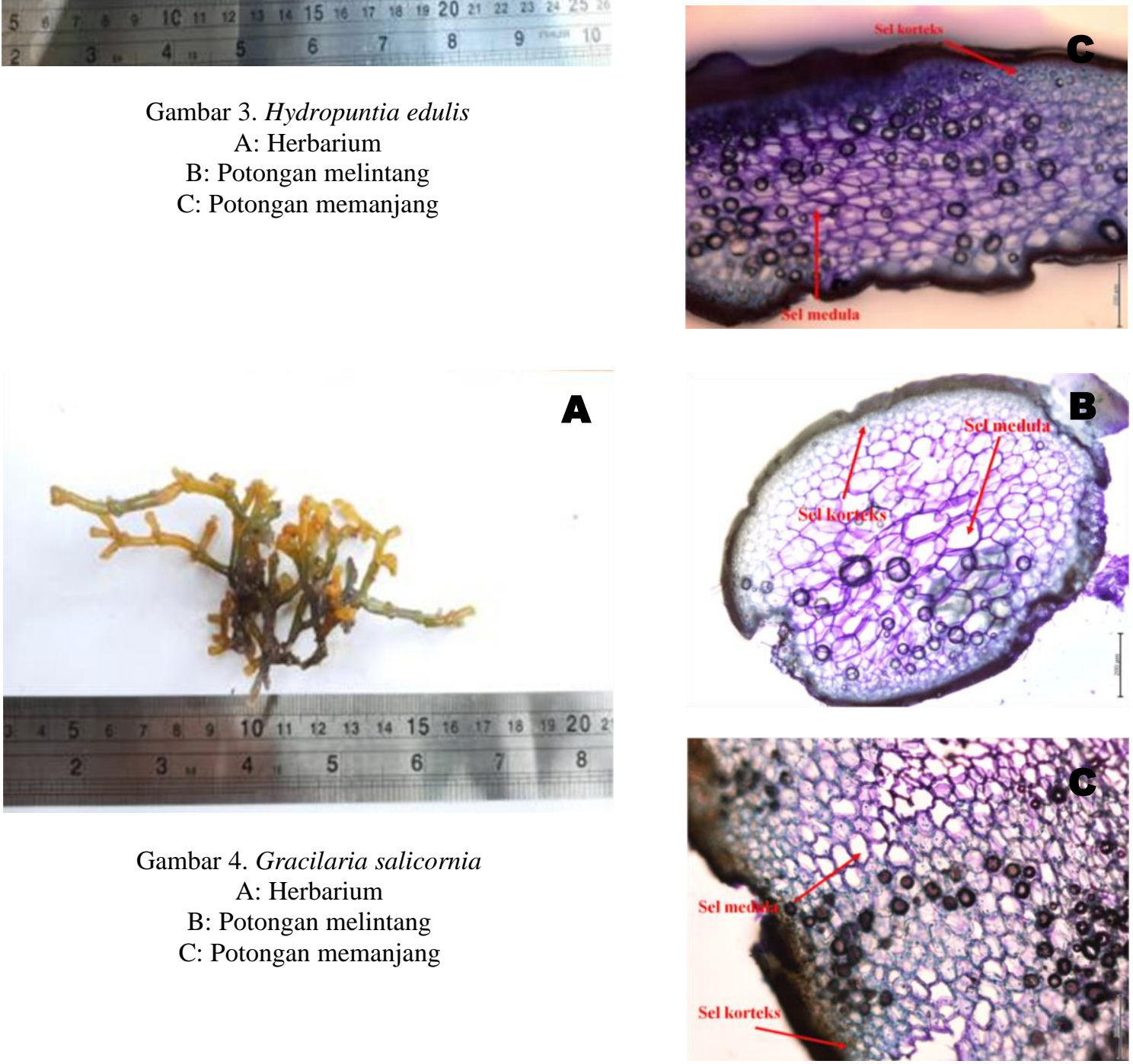

Turbinaria ornata (Turner) J. Agardh, 1848

Deskripsi: Thallus tegak dengan bentuk daun agak membulat, umumnya membentuk corong dengan dikelilingi gerigi yang tajam dan terletak tidak beraturan. Bagian tengah daun melengkung ke dalam dan mempunyai reseptakel yang melekat pada batang. Berwarna cokelat gelap dan membentuk alat pelekat (Gambar 7A-H).

Habitat: Substrat karang.

Menurut Pramesti et al. (2016), histologi struktur sel anatomi jenis makroalga dapat dibedakan menjadi dua jaringan dari luar ke dalam, yaitu korteks dan medula. Sel korteks tersusun atas satu lapisan. Korteks merupakan daerah antara epidermis dengan silindris pusat, terletak di bawah epidermis, sel-selnya tidak tersusun rapat sehingga banyak memiliki ruang antar sel (Farida, 2013). Sel medula hanya memiliki selapis sel dan ukurannya paling besar. Hal ini sesuai dengan hasil penelitian di mana dari 7 jenis yang diamati menunjukkan sel medula lebih besar dibandingkan sel korteks.

Lapisan korteks merupakan bagian kulit pertama, terdiri dari beberapa sel yang berada dekat 


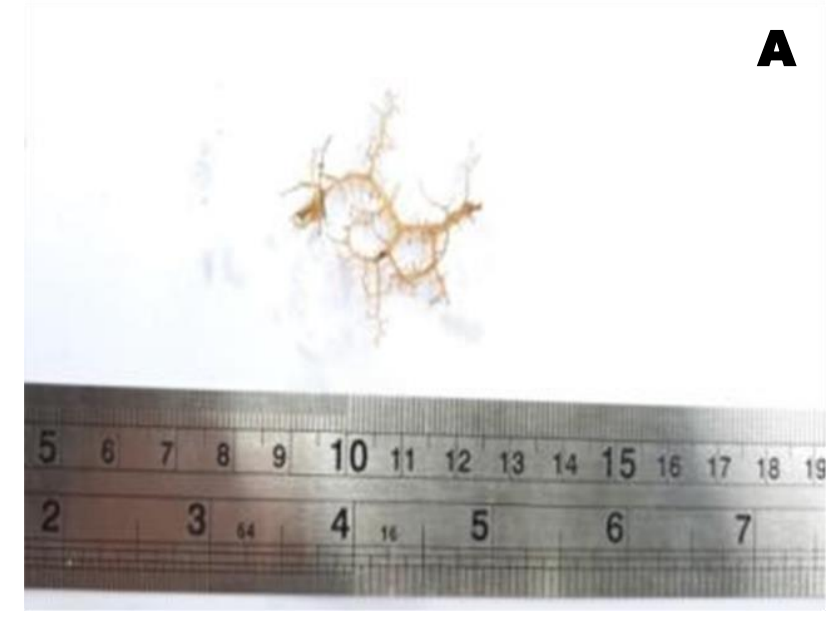

Gambar 5. Hypnea valentiae A: Herbarium

B: Potongan melintang

C: Potongan memanjang

dengan lapisan epidermis tersusun atas jaringan kolenkim, makin ke dalam tersusun atas jaringan parenkim. Hasil pengamatan menunjukkan, bentuk sel medula dari jenis $T$. ornata, $T$. deccurens, $H$. valentiae, G. salicornia, H. edulis, G. arcuata dan E. denticilatum makin mengecil ke arah sel korteks. Hal ini sesuai dengan penelitian yang dilakukan oleh Katamang et al. (2016) terhadap jenis Acanthophora spicifera dari Pantai Mokupa, Kabupaten Minahasa, Sulawesi Utara.

\section{KESIMPULAN}

Sel korteks tersusun atas satu lapisan atau lebih yang berukuran lebih besar dari epidermis, dan sel medula hanya memiliki selapis sel yang berukuran paling besar.

Ucapan terima kasih. Penulis mengucapkan terima kasih kepada semua pihak yang telah membantu dalam pelaksanaan penelitian dan penulisan naskah hasil penelitian untuk publikasi dalam jurnal ilmiah. "Kami menyatakan bahwa tidak ada konflik kepentingan dengan organisasi manapun mengenai bahan yang didiskusikan dalam naskah ini".

\section{REFERENSI}

BAINO, I., KEPEL, R.C. and MANU, G.D. (2019) Biodiversitas makroalga di perairan pesisir Desa Bahoi, Kecamatan Likupang Barat, Kabupaten
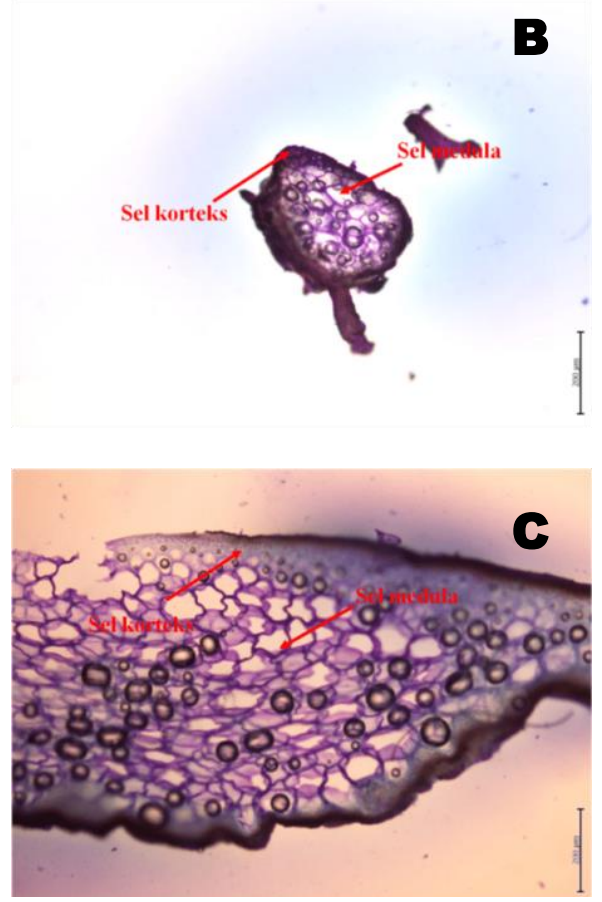

Minahasa. Jurnal Ilmiah Platax, 7 (1), pp. 134141.

CALUMPONG, H.P. and MEÑEZ, E.G. (1997) Field guide to the common mangroves: seagrasses and algae of the Philippines. Bookmark, Inc. Makati City, Philippines. 197 p.

FARIDA, N. (2013) Biologi struktur dan fungsi jaringan tumbuhan. https://media.neliti.com/ media/publications/276419-identifikasi-anatomitumbuhan-sirih-huta-79377308.pdf (diakses pada 1 Juli 2021).

KATAMANG, A.V., RUMAMPUK, N.D.C. and GERUNG, G.S. (2016) Telaah bentuk sel Acanthophora spicifera dari pantai beton panjang Mokupa, Sulawesi Utara. Jurnal Pesisir dan Laut Tropis, 1, pp. 26-29.

KEPEL, R.C., MANTIRI, D.M.H. and NASPRIANTO (2018a) Biodiversitas makroalga di perairan pesisir Tongkaina, Kota Manado. Jurnal Ilmiah Platax, 6 (1), pp. 160-173.

KEPEL, R.C., MANTIRI, D.M.H., RUMENGAN, A. and NASPRIANTO (2018b) Biodiversitas makroalga di perairan pesisir Desa Blongko, Kecamatan Sinonsayang, Kabupaten Minahasa Selatan. Jurnal Ilmiah Platax, 6 (1), pp. 174-187.

KEPEL, R.C. and MANTIRI, D.M.H. (2019) Biodiversitas Makroalga di Perairan Pesisir KoraKora, Kecamatan Lembean Timur, Kabupaten Minahasa. Jurnal Ilmiah Platax, 7 (2), pp. 49-59.

KEPEL, R.C., LUMINGAS, L.J.L., WATUNG, P.M.M. and MANTIRI, D.M.H. (2019a) Community structure of seaweeds along the intertidal zone of Mantehage Island, North 
Aquatic Science \& Management, Vol. 9, No. 2 (October 2021)

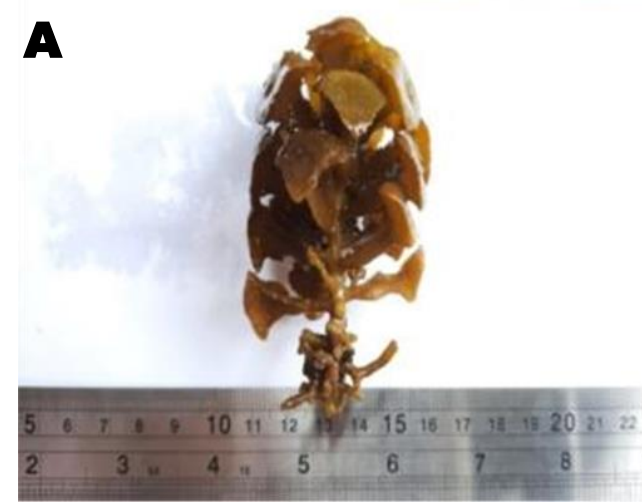

Gambar 6. Turbinaria deccurens
A: Potongan melintang blade
B: Potongan memanjang blade
C: Potongan melintang batang stipe
D: Potongan memanjang batang stipe
E: Potongan melintang holdfast
F: Potongan memanjang holdfast
$\mathrm{H}$ : Potongan melintang reseptakel
I: Potongan memanjang reseptakel
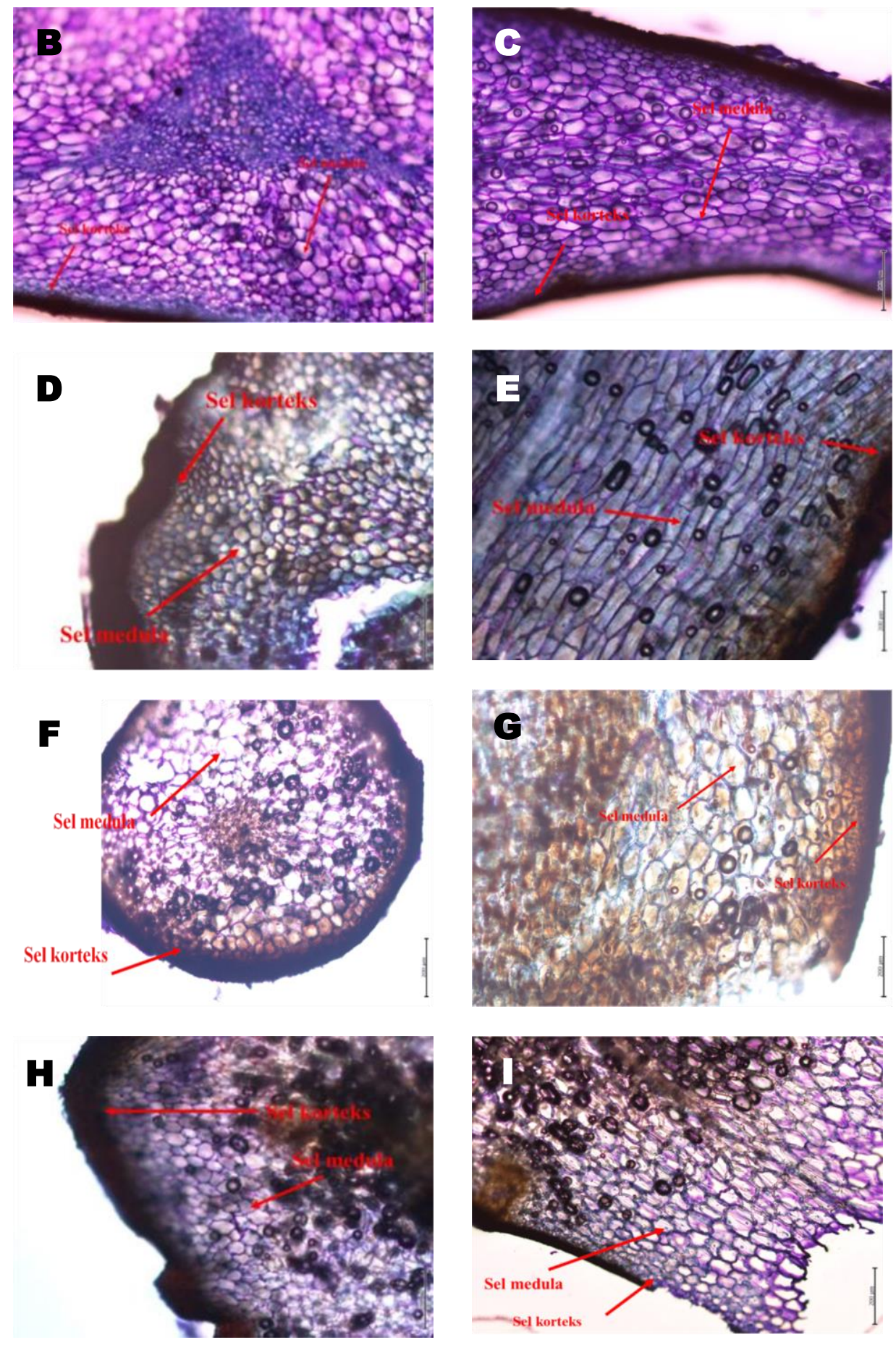
Patra et al.: Anatomical characteristics of macroalgal species from Bombuyanoi Island, ...

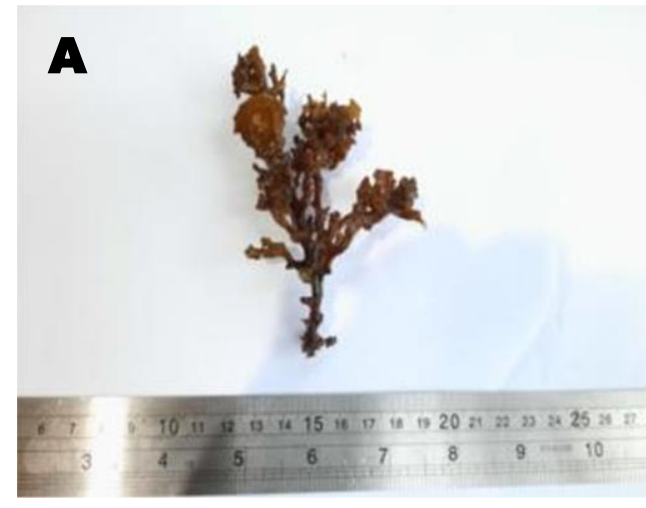

Gambar 7. Turbinaria ornata

A: Potongan melintang blade

B: Potongan memanjang blade

$\mathrm{C}$ : Potongan melintang batang stipe

D: Potongan memanjang batang stipe

E: Potongan melintang holdfast

F: Potongan memanjang holdfast

$\mathrm{H}$ : Potongan melintang reseptakel
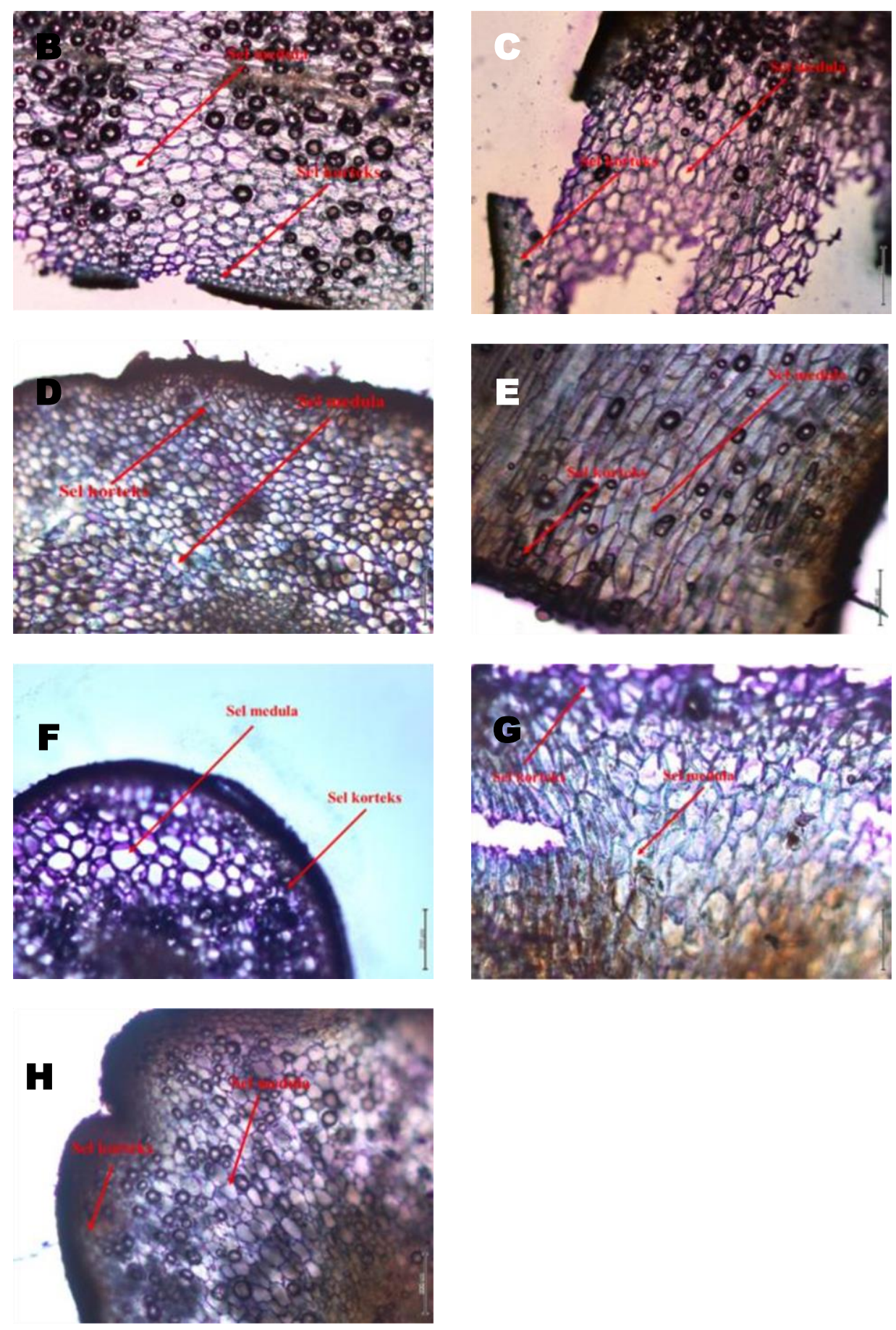
Sulawesi, Indonesia. AACL Bioflux, 12 (1), pp. 87-101.

KEPEL, R.C., LUMINGAS, L.J.L., TOMBOKAN, J.L. and MANTIRI, D.M.H. (2019b) Biodiversity and community structure of seaweeds in Minahasa Peninsula, North Sulawesi, Indonesia. AACL Bioflux, 12 (3), pp. 880-892.

KEPEL, R.C., Lumingas, L.J.L., TOMBOKAN, J.L. and MANTIRI, D.M.H. (2020) Community structure of seaweeds in dry season in Minahasa Peninsula, North Sulawesi, Indonesia. AACL Bioflux, 13 (1), pp. 392-402.

KREBS, C.J. (1999) Ecological methodology. Second Edition. Addison Wesley Longman, Inc. New York.

PRAMESTI, R., SUSANTO, A.B., RIDLO, W.S.A. and OKTAVIARIS, Y. (2016) Struktur komunitas dan anatomi rumput laut di perairan Teluk Awur, Jepara dan pantai Krakal,
Yogyakarta. Jurnal Kelautan Tropis, 19 (2), pp. 81-94.

TRONO, G.C. (1997) Field guide and atlas of the seaweed resources of the Philippines. Bookmarks, Inc. Makaty City, 306 p.

WATUNG, R.M., KEPEL, R.C. and LUMINGAS. L.J.L. (2016) Struktur komunitas makro alga di perairan pesisir Pulau Mantehage, Kabupaten Minahasa Utara, Sulawesi Utara. Jurnal Ilmiah Platax, 3 (1), pp. 30-35.

WOWOR, R.M., KEPEL, R.C. and LUMINGAS, L.J.L. (2015) Struktur komunitas makro alga di pantai Desa Mokupa Kecamatan Tombariri, Kabupaten Minahasa Sulawesi Utara. Jurnal Ilmiah Platax, 3 (1), pp. 30-35.

WoRMS (World Register of Marine Species). 2021. Marine Species. https://www.marinespecies.org/i ndex.php (diakses pada 1 Juli 2021). 